\title{
Review
}

\section{Neuronal life and death: an essential role for the p53 family}

\author{
FD Miller, ${ }^{*,}$, CD Pozniak ${ }^{1}$ and GS Walsh ${ }^{1}$ \\ ${ }^{1}$ Center for Neuronal Survival, Montreal Neurological Institute, McGill \\ University, 3801 rue University, Montreal, Canada H3A 2B4 \\ * Corresponding author: Dr FD Miller, Montreal Neurological Institute, 3801 rue \\ University, Montreal, Quebec, Canada H3A 2B4. Tel: (514) 398-4261; \\ Fax: (514) 398-1319; E-mail: mdfm@musica.mcgill.ca
}

Received 31.5.00; revised 4.7.00; accepted 5.7.00

Edited by G Melino

\begin{abstract}
Recent evidence indicates that the p53 tumor suppressor protein, and its related family member, p73, play an essential role in regulating neuronal apoptosis in both the developing and injured, mature nervous system. In the developing nervous system, they do so by regulating naturally-occurring cell death in neural progenitor cells and in postmitotic neurons, acting to ensure the apoptosis of cells that either do not appropriately undergo the progenitor to postmitotic neuron transition, or that fail to compete for sufficient quantities of trophic support. Somewhat surprisingly, in developing postmitotic neurons, p53 plays a proapoptotic role, while a naturally-occurring, truncated form of $p 73$, $\Delta \mathrm{Np} 73$, antagonizes $\mathrm{p} 53$ and plays an anti-apoptotic role. In the mature nervous system, numerous studies indicate that $p 53$ is essential for the neuronal death in response to a variety of insults, including DNA damage, ischemia and excitotoxicity. It is likely that all of these insults culminate in DNA damage, which may well be a common trigger for neuronal apoptosis. In this regard, the signaling pathways that are responsible for triggering p53-dependent neuronal apoptosis are starting to be elucidated, and involve cell cycle deregulation and activation of the JNK pathway. Finally, accumulating evidence indicates that $\mathrm{p} 53$ is perturbed in the CNS in a number of neurodegenerative disorders, leading to the hypothesis that longterm oxidative damage and/or excitotoxicity ultimately trigger p53-dependent apoptosis in the chronically degenerating nervous system. Cell Death and Differentiation (2000) 7, $880-888$.
\end{abstract}

Keywords: P53, P73; neuronal apoptosis; neurotrophins; DNA damage; excitotoxicity; oxidative stress; neurodegeneration; ischaemia; cell cycle

\footnotetext{
Abbreviations: Abeta, beta-amyloid protein; APP, amyloid precursor protein; AraC, cytosine arabinoside; ATM, ataxia telangiectasia mutated; BDNF, brain-derived neurotrophic factor; CNS, central nervous system; NGF, nerve growth factor; $p R b$, retinoblastoma protein; p75NTR, p75 neurotrophin receptor
}

The p53 tumor suppressor gene is the most frequently mutated gene in human tumors. As a tumor suppressor, p53 plays a key role in DNA damage repair, cell cycle regulation, and cellular apoptosis. The mechanisms that underly the ability of p53 to subserve these functions in cycling, nonneuronal cells have been intensively studied and are the subject of several recent reviews. ${ }^{1-3}$ We will not cover these topics in detail here, but will instead focus upon the role of p53 in neurons, a cell type that is 'forever' postmitotic, and that must survive and maintain its genome over as long as a century in humans. Moreover, we will discuss emerging evidence that the recently-described p53 family member, p73, also plays a major role in regulating development and survival in the nervous system.

\section{The p53 family and developmental apoptosis in the nervous system}

During nervous system development both progenitor cells and postmitotic neurons are overproduced, and the nervous system then chooses, through a process of elimination, those cells that have differentiated and made appropriate connections. It is now clear that the nervous system selects cells during two major periods of apoptosis. The first takes place in the ventricular and subventricular zones of the developing nervous systems, where neural stem and progenitor cells differentiate to produce the neurons and glial cells that will migrate and populate the brain and spinal cord. It is likely that this period of apoptosis serves two functions; to eliminate those progenitors that do not differentiate appropriately, and to ensure that the appropriate cell number is generated in rapidly-growing tissues such as the cerebral cortex. The existence of this period of apoptotic death has only recently been appreciated, and the mechanisms that control the life versus death of any given cell are still only poorly understood.

The second period of apoptotic death in the nervous system occurs once newly-born neurons have migrated to their final destinations, have extended their axons, and have attempted to establish appropriate connections. This period of naturally-occurring neuronal death eliminates approximately half of the neurons in any given population. ${ }^{4}$ In the peripheral nervous system, where this process has been extensively studied, neurons compete for limiting amounts of target-derived neurotrophins such as nerve growth factor (NGF), and their ultimate survival is dependent upon the interplay between receptormediated prosurvival and proapoptotic signals. ${ }^{5}$ Over the past several years, evidence has emerged implicating the p53 family in both of these periods of developmental apoptosis. 


\section{p53 is essential for the elimination of neural progenitor cells that fail to differentiate appropriately}

Mice that carry a null mutation in the p53 gene are born and survive until early adulthood, when they succumb to a variety of tumors, ${ }^{6}$ an observation that initially led to the conclusion that p53 was not involved in development. However, closer examination revealed that a significant portion of $\mathrm{p} 53^{-1-}$ embryos developed craniofacial abnormalities and died as a consequence of an overproduction of neural tissue and failed neural tube closure (exencephaly), ${ }^{7,8}$ indicating that $p 53$ was important in regulating neural development.

Additional evidence supporting a role for p53 in progenitor cell development came from studies of mice lacking the retinoblastoma tumor suppressor protein (pRb). ${ }^{9-11}$ The $\mathrm{Rb}^{-1-}$ mice die during embryogenesis, and have a striking nervous system phenotype consisting of ectopic mitoses and massive neural apoptosis. Further studies indicated (i) that this phenotype was due to the inability of newly-born neurons to undergo terminal mitosis in the absence of $\mathrm{pRb},{ }^{12-14}$ and (ii) that coincident deletion of p53 rescued the apoptotic phenotype in the $\mathrm{Rb}^{-1-}$ CNS. ${ }^{15,16}$ Thus, inappropriate terminal differentiation in the absence of $\mathrm{pRb}$ led to activation of a p53 default apoptotic pathway. The existence of this p53 apoptotic pathway in progenitors suggests that a major role for p53 is to eliminate neural progenitors that fail to differentiate appropriately. A deficit in this pathway in the $\mathrm{p} 53^{-1-}$ mice would provide at least a partial explanation for their exencephaly.

Insights into other potential players in this progenitor cell apoptotic pathway derive from recent studies of mice carrying null alleles in genes that are part of a death receptor-independent, intrinsic apoptotic pathway. ${ }^{17}$ This pathway, which can be activated by $p 53^{18}$ independently of its transcriptional function, ${ }^{24}$ involves release of cytochrome $c$ from the mitochondria, oligomerization and activation of Apaf-1 and caspase 9, and subsequent activation of caspase 3 and other effector caspases. ${ }^{17}$ Remarkably, animals mutant in each of Apaf $1,{ }^{19,20}$ caspase $9,{ }^{21}$ and caspase $3,{ }^{22,23}$ all display a dramatic overgrowth of neural tissue during embryogenesis, as a consequence of decreased progenitor cell apoptosis. Moreover, the Apaf1 $1^{-1-}$ mice display abnormalities in craniofacial structures, ${ }^{19,20}$ a phenotype also observed in the $p 53^{-1-}$ embryos. $^{8}$ These data therefore indicate that the intrinsic apoptotic pathway is critical during neural progenitor cell development and suggest that p53 is at least partially responsible for its activation.

\section{An essential role for p53 and p73 during naturally-occurring sympathetic neuron death}

A potential role for $\mathrm{p} 53$ in the apoptosis of postmitotic neurons was originally suggested by two sets of studies. First, a large number of studies documented increases in p53 following neural injury (reviewed below; Table 1). Second, overexpression of p53 was sufficient to induce the apoptosis of
Table 1 p53 is upregulated in response to many types of neural damage, and is necessary for the subsequent neuronal apoptosis

\begin{tabular}{llc}
\hline & $\begin{array}{c}\text { p53 } \\
\text { upregulation }\end{array}$ & $\begin{array}{c}\text { Necessity for } \\
\text { p53 in } \\
\text { apoptosis }\end{array}$ \\
\hline Excitotoxicity & $\mathrm{Yes}^{50,52-59,64}$ & $\mathrm{Yes}^{50,53}$ \\
Ischemia/hypoxia & es $^{60-65,67-70,72,73}$ & $\mathrm{Yes}^{66}$ \\
Adrenalectomy & $\mathrm{Yes}^{77,78}$ & Yes \\
Traumatic brain injury & $\mathrm{Yes}^{70,72-76}$ & $\mathrm{ND}$ \\
Dopamine-induced death & Yes $^{79}$ & $\mathrm{ND}$ \\
\hline
\end{tabular}

$\mathrm{ND}=$ not done

postmitotic sympathetic, ${ }^{25}$ hippocampal, ${ }^{26}$ and cortical $^{27}$ neurons. Since these original reports, a number of studies have been published demonstrating that p53 is necessary for neuronal apoptosis, either following neural injury (reviewed below; Table 1), or during naturally-occurring neuronal death. With regard to the latter, the best-characterized example involves sympathetic neurons of the peripheral nervous system, which we will focus upon here.

During development, peripheral sympathetic neurons become postmitotic, extend their axons to appropriate target tissues, and then about half of these neurons undergo apoptosis during the first 3 postnatal weeks. The survival of any given neuron during this period is determined by its ability to compete for limiting amounts of target-derived nerve growth factor (NGF). ${ }^{5} \mathrm{NGF}$ binds to the neuronal TrkA tyrosine kinase receptor, leading to the activation of a number of survival pathways, the most important of which is the Ras-PI3-kinase-Akt pathway. ${ }^{28,29}$ This pathway supports sympathetic neuron survival by overriding a receptor-mediated apoptotic signaling cascade that originates from a second neurotrophin receptor, the p75 neurotrophin receptor (p75NTR) ${ }^{28,29}$ Genetic support for this model derives from the findings that (i) all sympathetic neurons die in the $\operatorname{TrkA}^{-/-30}$ and $\mathrm{NGF}^{-/-31}$ mice, (ii) naturally-occurring sympathetic neuron death is greatly delayed in $\mathrm{p} 75 \mathrm{NTR}^{-1-}$ mice, ${ }^{32}$ and (iii) the coincident deletion of p75NTR rescues the sympathetic neuron death in the TrkA ${ }^{-1-}$ mice (M Majdan and $\mathrm{F}$ Miller, unpublished observations). Thus, sympathetic neurons are 'destined to die' as a consequence of an ongoing, p75NTRmediated apoptotic signal, and survive only if they sequester sufficient NGF to robustly activate TrkA.

A number of recent studies indicate that p53 and the related p73 play a key role in regulating the survival of sympathetic neurons during this developmental period. First, overexpression of p53 is sufficient to cause the death of sympathetic neurons in the presence of NGF. ${ }^{25}$ Second, Vogel and Parada ${ }^{33}$ demonstrated that embryonic

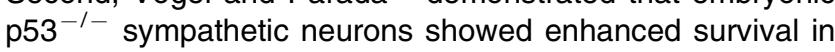
culture in the absence of NGF, their obligate survival factor. Third, Aloyz et al ${ }^{34}$ demonstrated that p53 levels increased when sympathetic neurons underwent apoptosis in response to either NGF withdrawal or activation of p75NTR, and that apoptosis could be inhibited if this increase in p53 levels was prevented. Moreover, developmental sympathetic neuron death was delayed (but not prevented) in the p53 $3^{-1-}$ mice. $^{34}$ Thus, p53 is important in an apoptotic 


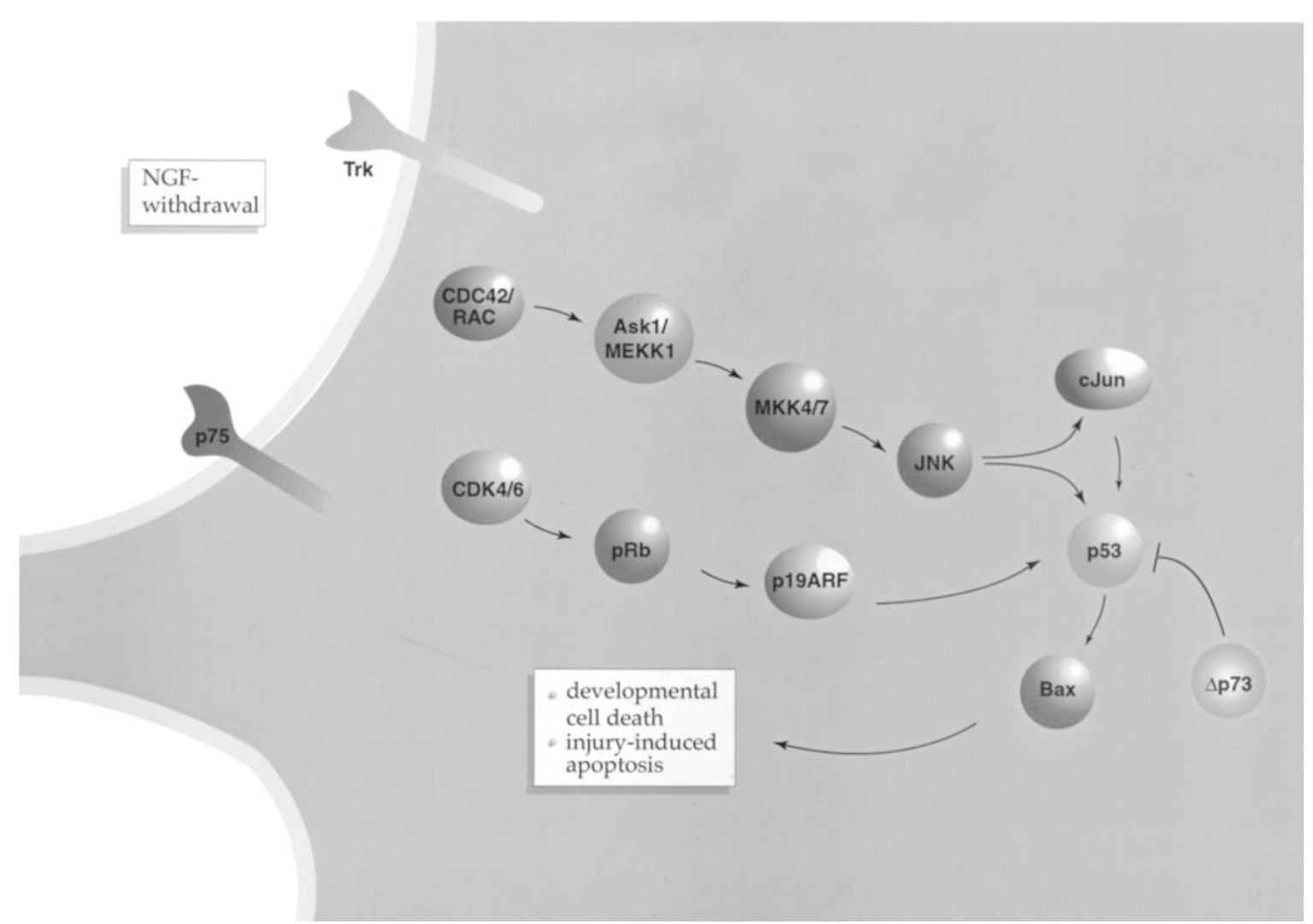

Figure 1 The role of $p 53$ and p73 in developmental neuron death. Naturally-occurring sympathetic neuron death is regulated by the balance of signals deriving from the NGF/TrkA prosurvival receptor and the proapoptotic, p75 neurotrophin receptor. ${ }^{5,28,29}$ Withdrawal of the survival ligand, NGF, or activation of the p75 neurotrophin receptor trigger two apoptotic signaling cascades, the JNK pathway and cell cycle deregulation, both of which are essential for neuronal apoptosis. P53 plays an essential proapoptotic role in this process, while a naturally-occurring truncated p 73 isoform, $\Delta N p 73$, plays an essential anti-apoptotic role, potentially by antagonizing p53. A more extensive discussion of these pathways is found in the text

signaling cascade that is activated following NGF withdrawal or p75 neurotrophin receptor activation.

What is this apoptotic signaling cascade? Evidence indicates that NGF withdrawal activates at least two apoptotic signaling pathways, both of which may converge onto p53 (Figure 1). One of these pathways, which is also activated by p75NTR, involves JNK-p53-Bax. ${ }^{34,35}$ MEKK and JNK function upstream of p53 in p75NTR-mediated apoptosis, ${ }^{34}$ while cdc42/Rac1, ${ }^{36}$ Ask1, ${ }^{37}$ MKK, JNK, cjun, ${ }^{38-40}$ and $p 53^{34}$ have been shown to act in a signaling pathway regulating NGF withdrawal-induced apoptosis. TrkA can silence the JNK-p53 arm of this pathway via Ras activation. ${ }^{29,41}$ A second pathway shown to be important for NGF withdrawal involves the activation of the cell cycle regulatory molecules CDK4/6, which activate $\mathrm{pRb}$ by phosphorylation, and subsequently cause sympathetic neuron apoptosis. ${ }^{42,43}$ Since pRb dysregulation (i) is known to cause p53 activation via p19ARF in nonneuronal cells, ${ }^{44}$ and (ii) leads to p53-dependent apoptosis in the embryonic nervous system (reviewed above), then it follows that this cell cycle pathway might also converge onto p53. If this were the case, then p53 would play a pivotal role in integrating neuronal apoptotic stimuli, perhaps thereby ensuring that apoptosis ensues only when these stimuli reach a certain critical threshold (Figure 1).
Surprisingly, the $p 53$ family member $p 73^{45-47}$ also plays an essential role in this system, but whereas p53 is proapoptotic, p73 is anti-apoptotic. A recent study by Pozniak et $a l^{48}$ indicates that the predominant isoform of p73 in the developing brain and sympathetic ganglia is truncated at the amino-terminus ( $\triangle \mathrm{Np} 73$ ), and lacks the transactivation domain. ${ }^{49}$ Levels of $\Delta N p 73 \beta$ are high in sympathetic neurons when they are maintained in NGF, but decrease dramatically when NGF is withdrawn; if this decrease is prevented by ectopic expression of $\Delta \mathrm{Np} 73$, neurons are rescued from apoptosis. Moreover, in $p 73^{-1-}$ mice ${ }^{49}$ developmental sympathetic neuron death is enhanced, indicating an essential anti-apoptotic role for p73 in these neurons. How does $\Delta$ Np73 inhibit sympathetic neuron apoptosis? $\Delta \mathrm{Np} 73$ can directly bind to $p 53$, at least in vitro, and can rescue p53-mediated death of sympathetic neurons. ${ }^{48}$ Thus, one mechanism whereby $\Delta$ Np73 might inhibit apoptosis is by binding to p53 and inhibiting its proapoptotic actions (Figure 1).

Does p73 play a similar anti-apoptotic role in other populations of developing or mature neurons? Although this question has not yet been answered, the phenotype of the $p 73^{-1-}$ mice indicates that p73 is essential for normal neural development. ${ }^{49}$ These mice display hippocampal dysgenesis, absence of certain neuronal 
subtypes in both the central and peripheral nervous systems, and many die showing greatly enlarged ventricles and decreased cortical tissue. Although there are several potential explanations for these phenotypes, they could be explained by the absence of an antiapoptotic activity in selected populations of CNS neurons and/or progenitors. Moreover, the truncated form of $\mathrm{p} 73 \beta$ that is predominantly observed in the developing brain ${ }^{48}$ is generated from the same gene as the full-length, proapoptotic form of $\mathrm{p} 73$ by alternative promoter usage, ${ }^{49}$ providing a mechanism for rapidly altering the ratios of the proapoptotic versus anti-apoptotic isoforms of p73 in the nervous system. In this regard, one potential explanation for the partial penetrance of the neural phenotype observed in the $\mathrm{p} 53^{-1-}$ embryos is that $\mathrm{p} 73$ may be able to compensate for the absence of p53 in the nervous system, at least with regard to developmental apoptosis. p73 may also play a role in differentiation; a recent publication ${ }^{132}$ indicates that full-length p73 causes differentiation of neuroblastoma cells, a finding that may well have implications for neural development.

\section{p53 and neuronal injury: p53 mediates neuronal apoptosis in response to DNA damage}

The apoptotic mechanisms underlying p53-mediated apoptosis in injured neurons are perhaps best-understood in the case of DNA damage. These studies have not only shed light on intracellular mechanisms that become increasingly important in long-lived cells, but have also provided insights into the neuronal apoptosis observed in acute injury and some forms of neurodegeneration. In this regard, we will discuss first the mechanistic insights gained studying DNA damage in neurons, and then the implications that these have for the traumatized nervous system.

A large body of work indicates that almost any DNAdamaging agent can cause the apoptosis of postmitotic neurons, including sympathetic, cortical, hippocampal and cerebellar neurons, and that in all cases this apoptosis is dependent upon p53 (Table 1). Examples include ionizing radiation, ${ }^{80-82}$ cytosine arabinoside (araC), ${ }^{83-86}$ DNA topoisomerase II inhibitors such as etoposide, ${ }^{81}$ cisplatin, ${ }^{87}$ and the topoisomerase I inhibitor camptothecin. ${ }^{88}$ Recent studies indicate that this activity is essential for the nervous system; absence of the DNA repair protein XRCC4 led to a massive neural apoptosis, presumably as a consequence of the accumulated DNA damage, and this apoptosis was rescued by coincident deletion of $p 53 .{ }^{89}$

How does DNA damage cause the activation and stabilization of p53? This question has perhaps been best answered for camptothecin-induced death of cortical neurons (Figure 2), but similar findings have been reported in other systems. Camptothecin leads to a rapid phosphorylation of $\mathrm{pRb}$ and $\mathrm{p} 107,,^{90}$ and increased levels of $\mathrm{p} 53$. This increase is likely to be at least partially mediated via a CDK4/6-pRb-E2F-p53 pathway, since camptothecin-induced apoptosis can be inhibited by dominant-inhibitory CDK4 or $6^{91,92}$ and dominant-inhibitory DP1, ${ }^{90}$ a binding partner for E2Fs. ${ }^{93,94}$ Moreover, both ionizing radiation-

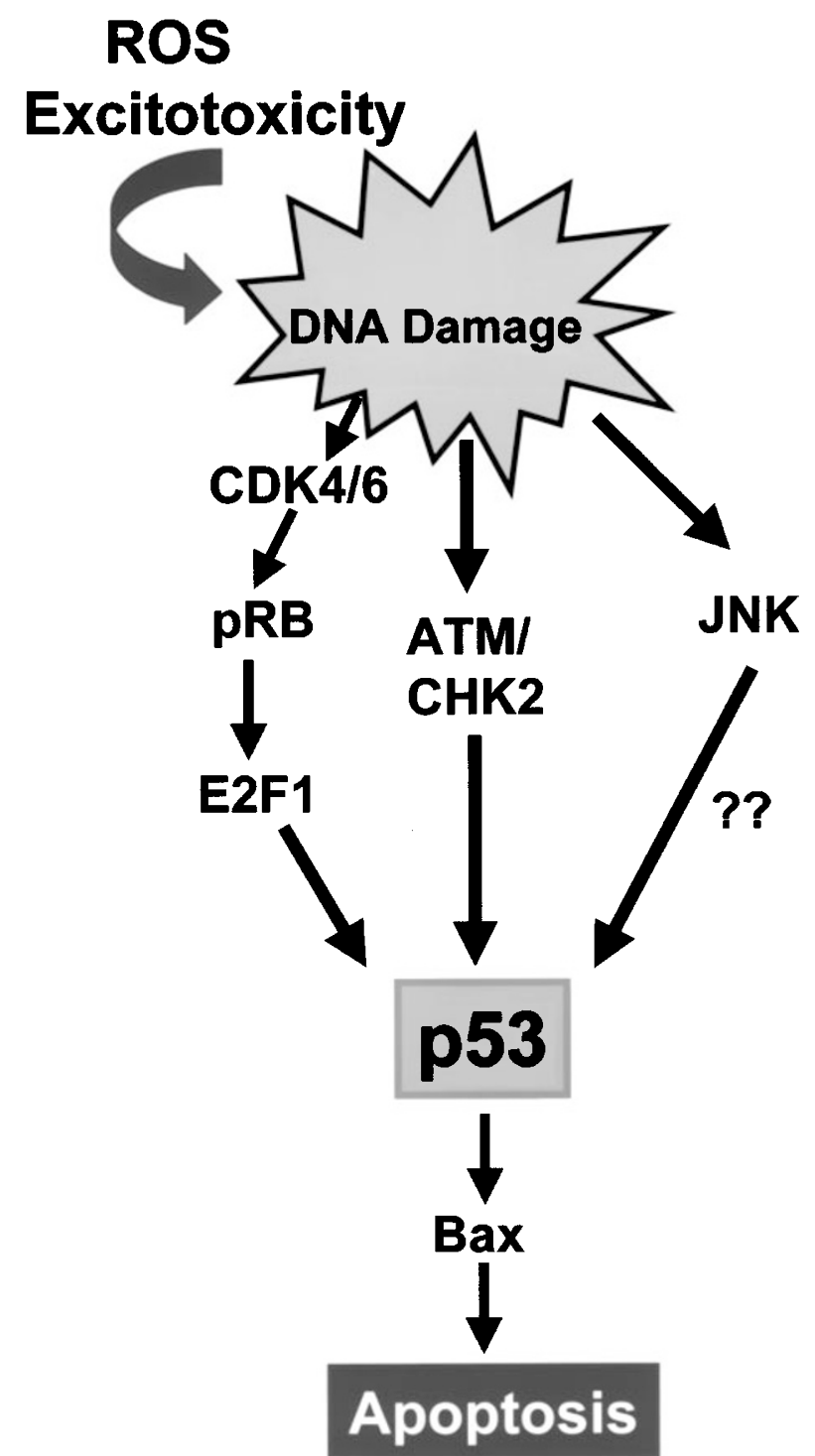

Figure 2 p53 is essential for neuronal apoptosis in response to DNA damage, excitotoxicity, and oxidative damage. Both oxidative damage and excitotoxicity cause DNA damage, and both cause neuronal apoptosis via a p53-dependent mechanism. DNA damage activates at least three signaling pathways, a cell cycle pathway, the JNK pathway, and ATM/CHK2, all of which are involved in the subsequent neuronal apoptosis. These pathways may be distinct from each other (as shown), or they may intersect upstream of p53. A more extensive discussion of these pathways is found in the text

induced death of hippocampal neurons ${ }^{26}$ and camptothecin-induced death of cortical neurons ${ }^{90}$ can be partially rescued by expression of a $\mathrm{pRb}$ mutant lacking phosphorylation sites, including the CDK4/6 site. Once p53 levels are increased, this in turn results in increased Bax levels and caspase activation; these downstream events are eliminated in $\mathrm{p} 53^{-1-}$ neurons. ${ }^{95}$ The activation of Bax is essential for apoptosis in response to both ionizing radiation $^{96}$ and camptothecin. ${ }^{95}$ However, caspase inhibitors either have no or limited effects, suggesting the possibility of caspase-independent apoptosis downstream of Bax..$^{97,98}$ That these alterations are essential for p53- 
mediated apoptosis is further supported by a recent study showing that the apoptosis observed following ectopic overexpression of p53 was abolished in $\mathrm{Bax}^{-1-}$ cerebellar granule neurons, and reduced in caspase $3^{-1-}$ neurons. ${ }^{99}$

A second potential mechanism for stabilization of p53 in response to DNA damage involves the product of the ataxia telangiectasia mutated (ATM) gene. ${ }^{100}$ AT is characterized by a spectrum of disorders, including progressive neurodegeneration that is most pronounced in the cerebellum. ATM is required for p53 stabilization in response to DNA damage, ${ }^{101}$ and can phosphorylate p53. ${ }^{102,103}$ The importance of this interaction in neurons derives from recent reports by McKinnon and colleagues ${ }^{101,104}$ who show that ionizing radiation is unable to induce neural apoptosis in $\mathrm{ATM}^{-1-}$ mice, a phenotype similar to that seen in $\mathrm{p} 53^{-1-}$ mice. ${ }^{101}$ Moreover, the increase in p53 that is observed following ionizing radiation in wild-type mice is absent in $\mathrm{ATM}^{-1-}$ mice, leading to the conclusion that ATM is upstream of p53. Interestingly, the $\mathrm{Bax}^{-1-}$ mice display a similar resistance to ionizing radiation, ${ }^{104}$ supporting the existence of an ATM-p53-Bax pathway (Figure 2). The recently-identified checkpoint kinase CHK2 is another potential player in this pathway; like ATM, CHK2 is required for p53 stabilization and apoptosis following ionizing radiation, ${ }^{105}$ supporting the notion that interactions between all three of these proteins are necessary for an appropriate DNA damage response. ${ }^{106}$ The point at which the CDK4/6-pRb-E2F1-p53 pathway intersects with the ATM/CHK2-p53 pathway in regulating neuronal apoptosis has not been defined (Figure 2).

Interestingly, the DNA damage-induced apoptosis of neurons can be rescued by growth factors. TGF $\beta$ rescues ionizing radiation-induced apoptosis of hippocampal neurons, ${ }^{26}$ and NGF and BDNF rescue araC and camptothecin-induced apoptosis of sympathetic ${ }^{107}$ and cortical neurons, ${ }^{108}$ respectively. In these latter two situations, the rescue is mediated as a consequence of Trk receptormediated activation of MEK.

\section{An essential role for p53 in neuronal apoptosis due to excitotoxicity and ischemia}

The first indication that p53 might be important for neuronal apoptosis following ischemia or excitotoxicity came from studies showing that p53 levels increased in response to these insults (Table 1). A similar elevation of p53 was observed in response to dopamine-neurotoxicity, ${ }^{79}$ traumatic brain injury, ${ }^{73}$ and adrenalectomy, ${ }^{77}$ the latter of which causes selective apoptosis of hippocampal granule cells (summarized in Table 1). In many of these injury paradigms, p53 is essential for apoptosis (Table 1). Of particular interest are studies demonstrating (i) that kainate was able to induce death of $\mathrm{p} 53^{+/+}$but not $\mathrm{p} 53^{-/-}$cortical and hippocampal neurons, even though intracellular calcium was elevated to the same degree in both populations of neurons, ${ }^{50}$ and (ii) that kainate-induced seizures led to significant apoptosis in $p 53^{+/+}$ but not $p 53^{-1-}$ mice. $^{52}$ These studies definitively established that p53 was an essential downstream component of NMDA receptor-mediated excitotoxicity. Similar studies have con- firmed that p53 is also essential for neuronal apoptosis following ischemia, ${ }^{65}$ adrenalectomy, ${ }^{78}$ and hypoxia. ${ }^{72}$

What is the molecular mechanism linking excitotoxin exposure to p53 activation? A number of lines of evidence indicate that it likely involves DNA damage. First, excitotoxicity may be associated with the accumulation of single-strand DNA breaks. ${ }^{109}$ Second, the alterations downstream of excitotoxicity are similar to those downstream of DNA damage in the same neurons. For example, in cortical neurons, excitotoxicity-induced apoptosis is blocked in $\mathrm{Bax}^{-1-}$ neurons, ${ }^{95}$ as it is in ${\mathrm{p} 53^{-1-}}^{-1}$ neurons, ${ }^{50}$ and there is little or no inhibition of this apoptosis with caspase inhibitors, ${ }^{97,98}$ findings very similar to those observed for camptothecin. ${ }^{97,98}$ One potential difference between these two pathways is upstream of p53; kainate-induced apoptosis is inhibited in $\mathrm{JNK}^{-1-}$ mice, ${ }^{110}$ but camptothecin-induced neuronal apoptosis is thought to be triggered by a CDK4/6-pRb-E2F-p53 pathway (Figure 2). However, a recent report indicates that DNA damageinduced apoptosis is inhibited in $\mathrm{JNK}^{-/-}$, $\mathrm{JNK}^{-1-}$ cells, ${ }^{11}$ suggesting either that there are two pathways to p53 following DNA damage, as there are following growth factor withdrawal (Figure 1), or that these two pathways intersect upstream of p53.

These findings suggest that the formation of DNA strand breaks is a key molecular event linking excitotoxic injury and the induction of apoptosis. How does this occur? Accumulating evidence has invoked a role for oxidative damage in the response to neuronal damage and, potentially in the degeneration of neurons in neurodegenerative diseases (discussed below). In this regard, glutamate receptor activation leads to the generation of reactive oxygen species. ${ }^{112,113}$ Reactive oxygen species are known to induce DNA strand breaks, and exposure of neurons to reactive oxygen species leads to neuronal apoptosis. ${ }^{114-117}$ Enhancement of p53 expression has been observed in numerous cell types following exposure to reactive oxygen species. ${ }^{118}$ Moreover, p53 is essential for neuronal apoptosis after exposure to stimuli that increase reactive oxygen species, such as ionizing radiation. $^{80,81}$ Taken together, these data suggest that any form of neuronal injury that produces an excess of free radicals, such as excitotoxic insults, could generate DNA strand breaks, which in turn could provide a signal for stabilizing and activating p53.

\section{Is p53 involved in neurodegeneration?}

Together, the aforementioned studies make a strong case that p53 is likely to be involved in the acute neuronal apoptosis that is observed following stroke or traumatic brain injury. However, the evidence implicating p53 in chronic neurodegeneration is largely indirect, and can be summarized as follows. First, p53 is increased in appropriate regions in the brains of individuals suffering from a number of neurodegenerative disorders. ${ }^{119-121}$ For example, p53 is increased in the temporal and frontal lobes of brains from Alzheimer's disease (AD) patients, in the spinal cord of ALS patients, and in the striatum of Parkinsons disease patients. ${ }^{121}$ Although there is as yet some controversy as to whether this increase is 
localized to neurons and/or glial cells, it is clear that p53 is elevated. Second, there is accumulating evidence that some neurodegenerative conditions involve oxidative or excitotoxic mechanisms, ${ }^{122-125}$ both of which would be predicted to cause DNA damage, and to potentially lead to p53-dependent apoptosis. For example, nitric oxide has recently been invoked in the motor neuron apoptosis observed in both familial and sporadic ALS. ${ }^{126}$ Finally, it is clear that any situation that leads to an increase in the DNA mutation load in neurons is likely to lead to neuronal death. In this regard, cancer chemotheraphy with agents such as cisplatin ${ }^{87}$ might trigger both short-term and long-term p53-dependent neuronal apoptosis. Alternatively, mutations that interfere with the repair system itself would be predicted to increase the mutation load, and potentially lead to a chronic and progressive neurodegeneration. The best example of this is the neurodegenerative disorder $A T ;^{100}$ it is likely that the inability to repair DNA using the ATM/p53 system ultimately causes neurodegeneration in a p53-independent fashion. In support of this idea, a recent study indicates that there is chronic and progressive neurodegeneration in the $\mathrm{p} 53^{-1-}$ mice. ${ }^{127}$ Although this finding may seem counterintuitive, it is likely that the inability to properly scan and repair DNA in the absence of p53 would ultimately lead to a nonfunctional neuron that would die by a p53-independent mechanism.

Of the few experimental studies exploring the role of p53 in neurodegeneration, most are focused upon $A D$. In one study, $\mathrm{Xu}$ et al $^{128}$ demonstrated that transfection of wildtype amyloid precursor protein (APP) into neuroblastoma cells was sufficient to rescue them from apoptosis induced by UV irradiation or by $\mathrm{p53}$ itself. However, a mutant form of APP found in familial Alzheimer's had no effect, leading to the hypothesis that APP protects neurons from apoptosis by controlling p53 and that mutations in APP could enhance neuronal vulnerability to p53-mediated apoptosis. In a second study, LaFerla et al ${ }^{129}$ examined a transgenic mouse expressing beta-amyloid protein (Abeta) in neurons, and found a correlation between Abeta accumulation in neurons, activation of p53 and DNA fragmentation. Both of these studies would predict that the elevated p53 found in $A D$ cortex might be important in the neurodegeneration. Arguing against this conclusion are two studies reporting that Abeta-mediated apoptosis did not require p53. ${ }^{130,131}$

Together, these studies highlight the difficulties of ascertaining the involvement of a given signaling pathway in human neurodegeneration. Nonetheless, the accumulating evidence that oxidative stress and excitotoxicity lead to p53-dependent apoptosis, and that perturbations in DNA repair can also lead to longterm neuronal degeneration, provide a strong argument for pursuing the potential involvement of p53 in a set of debilitating degenerative diseases for which we currently have no treatment.

\section{Acknowledgements}

We would like to thank David Kaplan for reading the manuscript and providing advice.

\section{References}

1. Bates S and Vousden KH (1999) Mechanisms of p53-mediated apoptosis. Cell Mol. Life Sci. 55: 28-37

2. Choisy-Rossi $C$ and Yonish-Rouach E (1998) Apoptosis and the cell cycle: the p53 connection. Cell Death Differ. 5: 129-131

3. Ko LJ and Prives C (1996) p53: puzzle and paradigm. Genes Dev. 10: 1054 1072

4. Oppenheim RW (1991) Cell death during development of the nervous system. Annu. Rev. Neurosci. 14: 453-501

5. Majdan M and Miller FD (1999) Neuronal life and death decisions: functional antagonism between the Trk and p75 neurotrophin receptors. Int. J. Devl. Neurosci. 17: 153-161

6. Donehower LA, Harvey M, Slagle BL, McArthur MJ and Montgomery CA (1992) Mice deficient for p53 are developmentally normal but susceptible to spontaneous tumors. Nature 356: 215-221

7. Sah VP, Attardi LD, Mulligan GJ, Williams BO, Bronson RT and Jacks T (1995)A subset of p53-deficient embryos exhibit exencephaly. Nature Genet. 10: 175179

8. Armstrong JF, Kaufman MH, Harrison DJ and Clarke AR (1995) High-frequency developmental abnormalities in p53-deficient mice. Curr. Biol. 5: 931-936

9. Clarke AR, Maandag ER, Vam Roon M, Van der Lugt NMT, Van der Valk M, Hooper MI, Berns A and Te Reile H (1992) Requirement for a functional Rb-1 gene in murine development. Nature 359: 328-330

10. Jacks T, Fazeli A, Schmitt EM, Bronson RT, Goodell MA and Weinberg RA (1992) Effects of an Rb mutation in the mouse. Nature 359: 295-300

11. Lee EHP, Chang CY, Hu N, Wang YCJ, LaiCC, HerrupK, LeeWHandBradley $A$ (1992) Mice deficient for $\mathrm{Rb}$ are nonviable and show defects in neurogenesis and haematopoiesis. Nature 359: 288-294

12. Lee E, Hu N, Yuan SSF, Cox LA, Bradley A, Lee W and Herrup K (1994) Dual roles of the retinoblastoma protein in cell cycle regulation and neuron differentiation. Genes Dev. 8: 2008-2021

13. Slack RS, El-Bizri H, Wong J, Belliveau DJ and Miller FD (1998) A critical temporal requirement for the $\mathrm{pRb}$ family during neuronal determination. J. Cell Biol. 140: 1497-1509

14. Tsai KY, Hu U, Macleod KF, Crowley D, Yamasaki L and Jacks T (1998) Mutation of E2F-1 suppresses apoptosis and inappropriate $S$ phase entry and extends survival of Rb-deficient mouse embryos. Mol. Cell. 3: 293-304

15. Morgenbesser SD, Jacks T and DePinho RA (1994) p53-dependent apoptosis produced by Rb-deficiency in the developing mouse lens. Nature 371: $72-74$

16. MacLeodKF, HuY and Jacks T (1996) Loss of Rb activates both p53-dependent and independent cell death pathways in the developing mouse nervous system. EMBO J. 15: 6178-6188

17. Green DR and Reed JC (1998) Mitochondria and apoptosis. Science 281: $1309-1312$

18. Soengas MS, Alarcon RM, Yoshida H, Giaccia AJ, Hakem R, Mak TW and Lowe SW (1999) Apaf-1 and caspase-9 in p53-dependent apoptosis and tumor inhibition. Science 284: 156-159

19. Yoshida H, Kong YY, Yoshida R, Elia AJ, Hakem A, Hakem R, Penninger JM and Mak TW (1998) Apaf1 is required for mitochondrial pathways of apoptosis and brain development. Cell 94: 739-750

20. Cecconi F, Alvarez-Bolado G, Meyer BI, Roth KA and Gruss P (1998) Apaf1 (CED-4 homolog) regulates programmed cell death in mammalian development. Cell 94: 727-737

21. Kuida K, Haydar TF, Kuan CY, Gu Y, Taya C, Karasuyama H, Su MS, Rakic P and Flavell RA (1998) Reduced apoptosis and cytochrome c-mediated caspase activation in mice lacking caspase 9. Cell 94: 325-337

22. Kuida K, Zheng TS, Na S, Kuan C-Y, Yang D, Karasuyama H, Rakic HP and Flavell RA (1996) Decreased apoptosis in the brain and premature lethality in CPP32-deficient mice. Nature 384: 368-372

23. Roth KA, Kuan C, Haydar TF, D'Sa-Eipper C, Shindler KS, Zheng TS, Kuida K, Flavell RA and Rakic P (2000) Epistatic and independent functions of caspase3 and $B x \mid-X(L)$ in developmental programmed cell death. Proc. Natl. Acad. Sci. USA 97: $466-471$

24. Schuler M, Bossy-Wetzel E, Goldstein JC, Fitzgerald P and Green DR (2000) p53 induces apoptosis by caspase activation through mitochondrial cytochrome c release. J. Biol. Chem. 275: 7337-7342 
25. Slack RS, Belliveau DJ, Rosenberg M, Atwal J, LochmullerH, Aloyz R, Haghighi A, Lach B, Seth P, Cooper E and Miller FD (1996) Adenovirus-mediated gene transfer of the tumor suppressor, p53, induces apoptosis in postmitotic neurons. J. Cell Biol. 135: 1085-1096

26. Jordan J, Galindo MF, Prehn JHM, Weichselbaum RR, Beckett M, Ghadge GD, Roos RP, Leiden JM and Miller RJ (1997) p53 expression induces apoptosis in hippocampal pyramidal neuron cultures. J. Neurosci. 17: 1397-1405

27. Xiang H, Hochman DW, Saya H, Fujiwara T, Schwartzkroin PA and Morrison RS (1996) Evidence for p53-mediated modulation of neuronal viability. J. Neurosci. 16: 6753-6765

28. Kaplan DR and Miller FD (1997) Signal transduction by the neurotrophin receptors. Curr. Opin. Cell. Biol. 9: 213-221

29. Kaplan DR and MillerFD (2000) Neurotrophin signal transduction in the nervous system. Curr. Opin. Neurobiol. 10: 381-391

30. Smeyne RJ, Klein R, Schnapp A, Long LK, Bryant S, Lewin A, Lira SA and Barbacid M (1994) Severe sensory and sympathetic neuropathies in mice carrying a disrupted Trk/NGF receptor gene. Nature 368: 246-248

31. Crowley C, Spencer SD, Nishimura MC, Chen KS, Pitts-Meek S, Armanini MP, Ling LH, McMahon SB, Shelton DL, Levinson AD and Phillips HS (1994) Mice lacking nerve growth factor display perinatal loss of sensory and sympathetic neurons yet develop basal forebrain cholinergic neurons. Cell 76: 1001-1011

32. Bamji SX, Majdan M, Pozniak CD, Belliveau DJ, Aloyz R, Kohn J, Causing GG and Miller FD (1998) The p75 neurotrophin receptor mediates neurona apoptosis and is essential for naturally-occurring sympathetic neuron death. J. Cell. Biol. 140: $911-923$

33. Vogel KS and Parada LF (1998) Sympathetic neuron survival and proliferation are prolonged by loss of p53 and neurofibromin. Mol. Cell. Neurosci. 11:19-28

34. Aloyz RS, Bamji SX, Pozniak CD, Toma JG, Atwal J, Kaplan DR and Miller FD (1999) p53 is essential for developmental neuron death as regulated by the TrkA and p75 neurotrophin receptors. J. Cell. Biol. 143: 1691-1703

35. Deckwerth TL, Elliott JL, Knudson CM, Johnson Jr EM, Snider WD and Korsmeyer SJ (1996) BAX is required for neuronal death after trophic factor deprivation and during development. Neuron 17: 401-411

36. Bazenet CE, Mota MA and Rubin LL (1998) The small GTP-binding protein $\mathrm{Cdc} 42$ is required for nerve growth factor withdrawal-induced neuronal death. Proc. Natl. Acad. Sci. USA 95: 3984-3989

37. Kanamoto T, Mota M, TakedaK, Rubin LL, MiyazonoK, Ichijo Hand BazenetCE (2000) Role of apoptosis signal-regulating kinase in regulation of the c-Jun nterminal kinase pathway and apoptosis in sympathetic neurons. Mol. Cell. Biol. 20: $196-204$

38. Estus S, Zaks WJ, Freeman RS, Gruda M, Bravo R and Johnson Jr EM (1994) Altered gene expression in neurons during programmed cell death: identification of c-jun as necessary for neuronal apoptosis. J. Cell. Biol. 127: $1717-1727$

39. Ham J, Babij C, Whitfield J, Pfarr CM, Lallemand D, Yaniv Mand Rubin LL (1995) A $c$-jun dominant negative mutant protects sympathetic neurons against programmed cell death. Neuron 14: 927-939

40. Eilers A, Whitfield J, Babij C, Rubin LL and Ham J (1998) Role of the jun kinase pathway in the regulation of $\mathrm{c}$-Jun expression and apoptosis in sympathetic neurons. J. Neurosci. 18: 1713-1724

41. Mazzoni IE, Said FA, Aloyz R, Miller FD and Kaplan DR (1999) Ras regulates sympathetic neuron survival by suppressing the p53-mediated cell death pathway. J. Neurosci. 19: 9716-9727

42. Park DS, Farinelli SE and Greene LA (1996) Inhibitors of cyclin-dependent kinases promote survival of post-mitotic neuronally differentiated PC12 cells and sympathetic neurons. J. Biol. Chem. 271: 8161-8170

43. Park DS, Levine B, Ferrari G and Greene LA (1997) Cyclin dependent kinase inhibitor and dominant negative cyclin dependent kinase 4 and 6 promote survival of NGF-deprived sympathetic neurons. J. Neurosci. 17: 8975-8983

44. Sherr CJ and Weber JD (2000) The ARF/p53 pathway. Curr. Opin. Genet. Dev. 10: $94-99$

45. Kaghad M, Bonnet H, Yang A, Creacier L, Biscan JC, Valent A, Minty A, Chalon P, Lellas JM, Dumont X, Ferrara P, McKeon F and Caput D (1997) Monoallelically expressed gene related to p53 at 1p36, a region frequently deleted in neuroblastoma and other human cancers. Cell 90: 809-819

46. Jost CA, Marin MC and Kaelin Jr WG (1997) p73 is a human p53 related protein that can induce apoptosis. Nature 389: 191-194
47. Levrero M, De Laurenzi V, Costanzo A, Gong J, Melino G and Wang JYJ (1999) Structure, function and regulation of p63 and p73. Cell Death Differ. 6: 11461153

48. Pozniak CD, Radinovic S, Yang A, McKeon F, Kaplan DR and Miller FD (2000) An anti-apoptotic role for the p53 family member, p73, during developmental neuron death. Science 289: 304-306

49. Yang A, Walker N, Bronson R, Kaghad M, Oosterwegal M, Bonnin J, Vagner C, Bonnet H, Dikkes P, Sharpe A, McKeon F and Caput D (2000) p73-deficient mice have neurological, pheromonal and inflammatory defects but lack spontaneous tumors. Nature 404: 99-103

50. Xiang H, Hochman DW, Saya H, Fujiwara T, Schwartzkroin PA and Morrison RS (1996) Evidence for p53-mediated modulation of neuronal viability. J. Neurosci. 16: 6753-6765

52. Morrison RS, Wenzel HJ, Kinoshita Y, Robbins CA, Donehower LA and Schwartzkroin PA (1996) Loss of the p53 tumor suppressor gene protects neurons from kainate-induced cell death. J. Neurosci. 16: 1337-1345

53. Sakhi S, Bruce A, Sun N, Tocco G, Baudry M and Schreiber SS (1994) p53 induction is associated with neuronal damage in the central nervous system. Proc. Natl. Acad. Sci. USA 91: 7525-7529

54. Sakhi S, Sun N, Wing LL, Mehta P and Schreiber SS (1996) Nuclear accumulation of p53 protein following kainic acid-induced seizures. NeuroReport 7: 493-496

55. Liu W, Rong Y, Baudry M and Schreiber SS (1999) Status epilepticus induces p53 sequence-specific DNA binding in mature rat brain. Brain Res. Mol. Brain Res. 63: $248-253$

56. Sakhi S, Bruce A, Sun N, Tocco G, Baudry M and Schreiber SS (1997) Induction of tumor suppressor p53 and DNA fragmentation in organotypic hippocampal cultures following excitotoxin treatment. Exp. Neurol. 145: 81-88

57. Liu X and Zhu XZ (1999) Roles of p53, c-myc, Bcl-2, Bax and caspases in glutamate-induced neuronal apoptosis and the possible neuroprotective mechanism of basic fibroblast growth factor. Brain Res. Mol. Brain Res. 71: $210-216$

58. Uberti D, Belloni M, Grilli M, Spano P and Memo M (1998) Induction of tumoursuppressor phosphoprotein p53 in the apoptosis of cultured rat cerebellar neurones triggered by excitatory amino acids. Eur. J. Neurosci. 10: 246-254

59. Hughes PE, Alexi T, Yoshida T, Schreiber SS and Knusel B (1996) Excitotoxic lesion of rat brain with quinolinic acid induces expression of p53 messenger RNA and protein and p53-inducible genes Bax and Gadd-45 in brain areas showing DNA fragmentation. Neuroscience 74: 1143-1160

60. Van Lookeren Campagne Mand Gill R (1998) Increased expression of cyclin G1 and $\mathrm{p} 21 \mathrm{WAF} 1 / \mathrm{CIP1}$ in neurons following transient forebrain ischemia: comparison with early DNA damage. J. Neurosci. Res. 53: 279-296

61. Tomasevic G, Kamme F, Stubberod P, Wieloch M and Wieloch T (1999) The tumor suppressorp53 and its response gene p21WAF1/Cip1 are not markers of neuronal death following transient global cerebral ischemia. Neuroscience 90: $781-792$

62. McGahan L, Hakim AM and Robertson GS (1998) Hippocampal myc and p53 expression following transient global ischemia. Brain Res. Mol. Brain Res. 56: $133-145$

63. Tomasevic G, Shamloo M, Israeli D and Wieloch T (1999) Activation of p53 and its target genes p21 (WAF1/Cip1) and PAG608/Wig-1 in ischemic preconditioning. Brain Res. Mol. Brain Res. 70: 304-313

64. Joo CK, Choi JS, Ko HW, Park KY, Sohn S, Chun MH, Oh YJ and Gwag BJ (1999) Necrosis and apoptosis after retinal ischemia: involvement of NMDAmediated excitotoxicity and p53. Invest. Opthalmol. Vis. Sci. 40: 713-720

65. Li Y, Chopp M, Zhang ZG, Zaloga C, Niewenhuis L and Gautam S (1994) p53immunoreactive protein and p53 mRNA expression after transient middle cerebral artery occlusion in rats. Stroke 25: 849-855

66. Crumrine RC, Thomas AL and Morgan PF (1994) Attenuation of p53 expression protects against focal ischemic damage in transgenic mice. J. Cereb. Blood Flow Metab. 14: 887-891

67. Li Y, Chopp M and Powers C (1997) Granule cell apoptosis and protein expression in hippocampal dentate gyrus after forebrain ischemia in the rat. J. Neurol. Sci. 150: 93-102

68. Li Y, Chopp M, Powers C and Jiang N (1997) Apoptosis and protein expression after focal cerebral ischemia in rats. Brain Res. 765: 301-312 
69. Watanabe H, Ohta S, Kumon Y, Sakaki S and Sakanaka M (1999) Increase in p53 protein expression following cortical infarction in the spontaneously hypertensive rat. Brain Res. 837: 38-45

70. Gillardon F, Spranger M, Tiesler C and Hossmann KA (1999) Expression of cell death-associated phospho-c-Jun and p53-activated gene 608 in hippocampal CA1 neurons following global ischemia. Brain Res. Mol. Brain Res. 73: 138143

72. Banasiak KF and Haddad GG (1998) Hypoxia-induced apoptosis: effect of hypoxic severity and role of p53 in neuronal cell death. Brain Res. 797: 295 304

73. Napieralski JA, Raghupathi R and McIntosh TK (1999) The tumor-suppressor gene, $p 53$, is induced in injured brain regions following experimental traumatic brain injury. Brain Res. Mol. Brain Res. 71: 78-86

75. Kaya SS, Mahmood A, Li Y, Yavuz E, Goksel M and Chopp M (1999) Apoptosis and expression of $p 53$ response proteins and cyclin D1 after cortical impact in rat brain. Brain Res. 818: 23-33

76. Manev H, Kharlamov A and Armstrong DM (1994) Photochemical brain injury in rats triggers DNA fragmentation, p53 and HSP72. Neuroreport 5: 2661-2664

77. Schreiber SS, Sakhi S, Dugich-Djordjevic MM and Nichols NR (1994) Tumor suppressor p53 induction and DNA damage in hippocampal granule cells after adrenalectomy. Exp. Neurol. 130: 368-376

78. Sakhi S, Gilmore W, Tran ND and Schreiber SS (1996) p53-deficient mice are protected against adrenalectomy-induced apoptosis. Neuroreport 8: 233-235

79. Daily D, Barzilai A, Offen D, Kamsler A, Melamed E and Ziv I (1999) The involvement of p53 in dopamine-induced apoptosis of cerebellar granule neurons and leukemic cells overexpressing p53. Cell. Mol. Neurobiol. 19: $261-276$

80. Wood KA and Youle RJ (1995) The role of free radicals and p53 in neuron apoptosis in vivo. J. Neurosci. 15: 5851-5857

81. Enokido Y, Araki T, Tanaka K, Aizawa S and Hatanaka H (1996) Involvement of p53 in DNA strand break-induced apoptosis in postmitotic CNS neurons. Eur.J. Neurosci. 8: 1812-1821

82. Johnson MD, Xiang H, London S, Kinoshita $\mathrm{Y}$, Knudson M, Mayberg M, Korsmeyer SJ and Morrison RS (1998) Evidence for involvement of Bax and p53, but not caspases, in radiation-induced cell death of cultured postnatal hippocampal neurons. J. Neurosci. Res. 54: 721-733

83. Winkelman HD and Hines JD (1983) Cerebellar degeneration caused by highdose cytosine arabinoside: a clinicopathological study. Ann. Neurol. 14: 520527

84. Martin DP, Wallace TL and Johnson Jr EM (1990) Cytosine arabinoside kills postmitotic neurons in a fashion resembling trophic factor deprivation: evidence that a deoxycytidine-dependent process may be required for nerve growth factor signal transduction. J. Neurol. 10: 184-193

85. Wallace TL and Johnson Jr EM (1989) Cytosine arabinoside kills postmitotic neurons: evidence that deoxycytidine may have a role in neuronal survival that is independent of DNA synthesis. J. Neurosci. 9: 115-124

86. Tomkins CE, Edwards SN and Tolkovsky AM (1994) Apoptosis is induced in post-mitotic rat sympathetic neurons by arabinosides and topoisomerase II inhibitors in the presence of NGF. J. Cell. Sci. 107: 1499-1507

87. Windebank AJ (1999) Chemotherapeutic neuropathy. Curr. Opin. Neurol. 12: $565-571$

88. Morris EJ and Geller HM (1996) Induction of neuronal apoptosis by camptothecin, an inhibitor of DNA topoisomerase-l: evidence for cell cycleindependent toxicity. J. Cell Biol. 134: 757-770

89. Gao Y, Ferguson DO, Xie W, Manis JP, Sekiguchi J, Frank KM, Chaudhuri J, Horner J, DePinho RA and Alt FW (2000) Interplay of p53 and DNA-repair protein XRCC4 in tumorigenesis, genomic stability and development. Nature 404: $897-900$

90. Park DS, Morris EJ, Bremmer R, Keramaris E, Padmanabhan J, Rosenbaum M, Shelanski ML, Geller HM and Greene LA (2000) Involvement of retinoblastoma family members and E2F/EP complexes in the death of neurons evoked by DNA damage. J. Neurosci. 20: 3104-3114

91. Park DS, Morris EJ, Greene LA and Geller HM (1997) G1/S cell cycle blockers and inhibitors of cyclin-dependent kinases suppress camptothecin-induced neuronal apoptosis. J. Neurosci. 17: 1256-1270

92. Park DS, Morris EJ, Padmanabhan J, Shelanski ML, Geller HM and Greene LA (1998) Cyclin dependent kinases participate in death of neurons evoked by DNA damaging agents. J. Cell Biol. 143: 457-467
93. Girling R, Partridge JF, Bandara N, Totty NF, Hsuan JJ and La Thangue NB (1993) A new component of the transcription factor DRTF1/E2F. Nature 362: $83-87$

94. La Thangue NB (1994) DTRF1/E2F: an extended family of heterodimeric factors implicated in cell cycle controls. Trends Biochem. Sci. 19: 108-114

95. Xiang H, Kinoshita $Y$, Knudson CM, Korsmeyer SJ, Schwartzkroin PA and Morrison RS (1998) Bax involvement in p53-mediated neuronal cell death. J. Neurosci. 18: 1363-1373

96. Johnson MD, Xiang $\mathrm{H}$, London S, Kinoshita $\mathrm{Y}$, Knudson M, Mayberg M, Korsmeyer SJ and Morrison RS (1998) Evidence for involvement of BAX and p53, but not caspases, in radiation-induced cell death of cultured postnatal hippocampal neurons. J. Neurosci. Res. 54: 721-733

97. Stefanis L, Park DS, Friedman WJ and Greene LA (1999) Caspase-dependent and -independent death of camptothecin-treated embryonic cortical neurons. J. Neurosci. 19: 6235-6247

98. Johnson MD, Kinoshita Y, Xiang H, Ghatan S and Morrison RS (1999) Contribution of p53-dependent caspase activation to neuronal cell death declines with neuronal maturation. J. Neurosci. 19: 2996-3006

99. Cregan SP, MacLaurin JG, Craig CG, Robertson GS, Nicholson DW, Park DS and Slack RS (1999) Bax-dependent caspase-3 activation is a key determinant in p53-induced apoptosis in neurons. J. Neurosci. 19: 7860-7869

100. Shiloh Y (1997) Ataxia-telangiectasia and the Nijmegen breakage syndrome: related disorders but genes apart. Annu. Rev. Genet. 31: 635-662

101. Herzog KH, Chong MJ, Kapsetaki M, Morgan JI and McKinnon PJ (1998) Requirement for Atm in ionizing radiation-induced cell death in the developing central nervous system. Science 280: 1089-1091

102. Canman CE, Lim DS, Cimprich KA, Taya Y, Tamai K, Sakaguchi K, Appella E, Kastan MB and Siliciano JD (1998) Activation of the ATM kinase by ionizing radiation and phosphorylation of p53. Science 281: 1677-1679

103. Banin S, Moyal L, Shieh S, Taya Y, Anderson CW, Chessa L, Smorodinsky NL, Prives C, Reiss Y, Shiloh Y and Ziv Y (1998) Enhanced phosphorylation of p53 by ATM in response to DNA damage. Science 281: 1674-1677

104. Chong MJ, Murray MR, Gosink EC, Russell HR, Srinivasan A, Kapsetaki M, Korsmeyer SJ and McKinnon PJ (2000) Atm and Bax cooperate in ionizing radiation-induced apoptosis in the central nervous system. Proc. Natl. Acad. Sci. USA 97: 889-894

105. Hirao A, Kong Y-Y, Matsuoka S, Wakeham A, Ruland J, Yoshida H, Liu D, Elledge SJ and Mak TW (2000) DNA damage-induced activation of p53 by the checkpoint kinase Chk2 (2000). Science 287: 1824-1827

106. Carr AM (2000) Piecing together the p53 puzzle. Science 287: 1765-1766

107. Anderson CNG and Tolkovsky AM (1999) A role for MAPK/ERK in sympathetic neuron survival: protection against a p53-dependent, JNK-independent induction of apoptosis by cytosine arabinoside. J. Neurosci. 19: 664-673

108. Hetman M, Kanning K, Cavanaugh JE and Xia Z (1999) Neuroprotection by brain-derived neurotrophic factor is mediated by extracellular signal-regulated kinase and phosphatidylinositol 3-kinase. J. Biol. Chem. 274: 22567-22580

109. Didier M, Bursztajn S, Adamec E, Passani L, Nixon RA, Coyle JT, Wei JY and Berman SA (1996) DNA strand breaks induced by sustained glutamate excitotoxicity in primary neuronal cultures. J. Neurosci. 16: 2238-2250

110. Yang DD, Kuan CY, Whitmarsh AJ, Rincon M, Zheng TS, Davis RJ, Rakic P and Flavell RA (1997) Absence of excitotoxicity-induced apoptosis in the hippocampus of mice lacking the Jnk3 gene. Nature 389: 865-870

111. Tournier C, Hess P, Yang DD, Xu J, Turner TK, Nimnual A, Bar-Sagi D, Jones SN, Flavell RA and Davis RJ (2000) Requirement of JNK for stress-induced activation of the cytochrome c-mediated death pathway. Science 288: 870874

112. Bondy SC and Lee DK (1993) Oxidative stress induced by glutamate receptor agonists. Brain Res. 610: 229-233

113. Lafon-Cazal M, Culcasi M, Gaven F, Pietri S and BockaertJ (1993) Nitric oxide, superoxide and peroxynitrite: putative mediators of NMDA-induced cell death in cerebellar granule cell. Neuropharmacology 32: 1259-1266

114. Enokido $\mathrm{Y}$ and Hatanaka $\mathrm{H}$ (1993) Apoptotic cell death occurs in hippocampal neurons cultured in a high oxygen atmosphere. Neurosci. 57: 965-972

115. Whittemore ER, Loo DT and Cotman CW (1994) Exposure to hydrogen peroxide induces cell death via apoptosis in cultured rat cortical neurons. Neuroreport 5: $1485-1488$ 
116. Yamada M, Enokido Y, Ikeuchi T and Hatanaka H (1995) Epidermal growth factor prevents oxygen-triggered apoptosis and induces sustained signalling in cultured rat cerebral cortical neurons. Eur. J. Neurosci. 7: 2130-2138

117. Ciriolo MR, De Martino A, Lafavia E, Rossi L, Carri MT and Rotilio G (2000) $\mathrm{Cu}, \mathrm{Zn}$-superoxide dismutase-dependent apoptosis induced by nitric oxide in neuronal cells. J. Biol. Chem. 275: 5065-5072

118. Y J, Wang S, Leonard SS, Sun Y, Butterworth L, Antonin J, Ding M, Rojanasakul Y, Vallyathan V, Castranova V and Shi X (1999) Role of reactive oxygen species and p53 in chromium (VI)-induced apoptosis. J. Biol. Chem. 274 $34974-34980$

119. Kitamura $Y$, Shimohama S, Kamoshima W, Matsuoka $Y$, Nomura $Y$ and Taniguchi T (1997) Changes of p53 in the brains of patients with Alzheimer's disease. Biochem. Biophys. Res. Commun. 232: 418-421

120. De la Monte SM, Sohn YK and Wands JR (1997) Correlates of p53- and Fas (CD95)-mediated apoptosis in Alzheimer's disease. J. Neurol. Sci. 152: 73-83

121. De la Monte SM, Sohn YK, Ganju N and Wands JR (1998) p53- and CD95associated apoptosis in neurodegenerative diseases. Lab. Invest. 78: 401 411

122. Beal MF (1996) Mitochondria, free radicals, and neurodegeneration. Curr. Opin. Neurobiol. 6: 661-666

123. Shaw PJ and Ince PG (1997) Glutamate, excitotoxicity and amyotrophic lateral sclerosis. J. Neurol. 244: 3-14.

124. Grunewald T and Beal MF (1999) Bioenergetics in Huntington's disease. Ann. N.Y. Acad. Sci., 893: 203-213

125. Markesbery WR (1997) Oxidative stress hypothesis in Alzheimer's disease. Free Radic. Biol. Med. 23: 134-147
126. Estevez AG, Crow JP, Sampson JB, Reiter C, Zhuang Y, Richardson GJ, Tarpey MM, Barbeito L and Beckman JS (1999) Induction of nitric oxidedependent apoptosis in motor neurons by zinc-deficient superoxide dismutase. Science 286: $2498-2500$

127. Amson R, Lassalle JM, Halley H, Prieur S, Lethrosne F, Roperch JP, Israeli D, Gendron MC, Duyckaerts C, Checler F, Dausset J, Cohen D, Oren M and Telerman A (2000) Behavioral alterations associated with apoptosis and downregulation of presenilin 1 in the brains of p53-deficient mice. Proc. Natl. Acad. Sci. USA 97: 5346-5350

128. XuX, Yang D, Wyss-Coray T, Yan J, Gan L, Sun Y and Mucke L (1999) Wild-type but not Alzheimer-mutant amyloid precursor protein confers resistance against p53-mediated apoptosis. Proc. Natl. Acad. Sci. USA 96: 7547-7552

129. LaFerla FM, Hall CK, Ngo L and Jay G (1996) Extracellular deposition of betaamyloid upon p53-dependent neuronal cell death in transgenic mice. J. Clin. Invest. 98: 1626-1632

130. Blasko I, Wagner M, Whitaker N, Grubeck-Loebenstein B and Jansen-Durr $P$ (2000) The amyloid beta peptide abeta (25-35) induces apoptosis independent of p53. FEBS Lett. 470: 221-225

131. Giovanni A, Keramaris E, Morris EJ, Hou ST, O'Hare M, Dyson N, Robertson GS, Slack RS and Park DS (2000) E2F1 mediates death of B-amyloid-treated cortical neurons in a manner independent of $\mathrm{p} 53$ and dependent on Bax and caspase 3 (2000). J. Biol. Chem. 275: 11553-11560

132. De Laurenzi V, Raschella G, Barcaroli D, Annicchiarico-Petruzzelli M, Ranalli M, Catani MV, Tanno B, Costanzo A, Levrero M and Melino G (2000) Induction of neuronal differentiation by p73 in a neuroblastoma cell line. J. Biol. Chem. 275: $15226-15231$ 